\title{
Atmospheric stilling leads to prolonged thermal stratification in a large shallow polymictic lake
}

\author{
R. Iestyn Woolway ${ }^{1} \cdot$ Pille Meinson $^{2} \cdot$ Peeter Nõges $^{2}$ • \\ Ian D. Jones ${ }^{3}$. Alo Laas ${ }^{2}$
}

Received: 16 September 2016 / Accepted: 21 January 2017 /Published online: 2 February 2017

(C) The Author(s) 2017. This article is published with open access at Springerlink.com

\begin{abstract}
To quantify the effects of recent and potential future decreases in surface wind speeds on lake thermal stratification, we apply the one-dimensional process-based model MyLake to a large, shallow, polymictic lake, Võrtsjärv. The model is validated for a 3-year period and run separately for 28 years using long-term daily atmospheric forcing data from a nearby meteorological station. Model simulations show exceptionally good agreement with observed surface and bottom water temperatures during the 3-year period. Similarly, simulated surface water temperatures for 28 years show remarkably good agreement with long-term in situ water temperatures. Sensitivity analysis demonstrates that decreasing wind speeds has resulted in substantial changes in stratification dynamics since 1982, while increasing air temperatures during the same period had a negligible effect. Atmospheric stilling is a phenomenon observed globally, and in addition to recent increases in surface air temperature, needs to be considered when evaluating the influence of climate change on lake ecosystems.
\end{abstract}

\section{Introduction}

Thermal stratification is a natural phenomenon that occurs in lakes as a result of the thermal expansion properties of water. It is determined by the balance between turbulence, which acts to enhance mixing, and buoyancy forces, which act to suppress turbulence and result in a vertical layering (Boehrer and Schultze 2008). The epilimnion is defined as that part of the water column immediately below the water surface, directly influenced by atmospheric

R. Iestyn Woolway and Pille Meinson are considered to be joint lead authors.

R. Iestyn Woolway

riwoolway@gmail.com

1 Department of Meteorology, University of Reading, Reading, UK RG6 6BB

2 Institute of Agricultural and Environmental Sciences, Centre for Limnology, Estonian University of Life Sciences, Tartu, Estonia

3 Centre for Ecology \& Hydrology, Lancaster Environment Centre, Lancaster LA1 4AP, UK 
forcing. The hypolimnion, the coolest and densest layer, lies in contact with the bottom of the lake and is separated from the epilimnion above by a temperature-driven density gradient known as the thermocline. The vertical layering that exists during stratification has several implications for the ecosystem, as it not only inhibits the downward penetration of direct vertical mixing and thus influences temperatures at depth (Livingstone 2003) but it also separates processes of production and nutrient depletion in the epilimnion from processes of decomposition and nutrient regeneration in the hypolimnion and sediment.

Stratification can be transient or persistent, and its duration can vary from hours to months or even be permanent in some lakes. For lakes of sufficient depth, the water column typically evolves seasonally from being isothermal in the early spring, developing stratification as the weather warms and then overturning sometime in the autumn. Some shallow lakes, however, do not develop a full seasonal stratification but rather experience alternate periods of mixing and stratification driven strongly by meteorological conditions. These lakes are often termed polymictic and, according to Hutchinson's (1957) mixing classification, are among the most abundant at mid-latitudes. Polymictic lakes can be categorised further into continuous and discontinuous polymictic, depending on whether stratification occurs at most on a daily basis or for periods of several days to weeks, but with irregular interruption by mixing events (Lewis 1983). The mixing class a lake belongs to is mostly determined by lake morphometry, although the strength and extent of stratification are also influenced by extrinsic features of a lake, such as altitude (Woolway et al. 2015a), inflows (Rimmer et al. 2011), and meteorological conditions (Churchill and Kerfoot 2007), and intrinsic factors such as water clarity (Heiskanen et al. 2015).

Mixing regime shifts, the term used to describe a change in the mixing classification of lakes, have been reported (Shatwell et al. 2016), and polymictic lakes have been described as particularly susceptible to mixing regime shifts due to climate change (Kirillin 2010). Despite the ubiquitous recognition that climate change affects lake stratification (Verburg and Hecky 2009), most studies typically only consider the response of a lake to increasing air temperature (Elo et al. 1998). Climate, however, is much more than temperature and studies have found climate-induced changes in a number of other meteorological variables known to influence lake stratification, including cloud cover (Eastman and Warren 2013) and solar radiation (Wild 2012). In addition, several studies have shown that, in recent years, wind speeds from around the world have been decreasing, in a phenomenon termed atmospheric stilling, where observations indicate that the annual land 10-m wind speed has decreased during the past few decades (Vautard et al. 2010), attributed to, among other things, increased surface roughness (Vautard et al. 2010; Bichet et al. 2012), and changes in urbanisation (Xu et al. 2006).

Despite the recognition that wind stress is one of the most important factors driving mixing in lakes, the response of lake stratification to atmospheric stilling has not yet been investigated. In this contribution, we aim to address this research gap by investigating the response of a large (average surface area $270 \mathrm{~km}^{2}$ ) and shallow (mean depth of $2.8 \mathrm{~m}$; maximum depth $=6.1 \mathrm{~m}$ ) lake, Võrtsjärv, to decreasing surface wind speeds. Traditionally, Võrtsjärv has been classified as continuous polymictic (Jaani 1973; Nõges \& Nõges 2012; Laas et al. 2012), but recent high frequency in situ temperature measurements demonstrate that the lake now stratifies occasionally, thus suggesting a shift to a discontinuous polymictic state. The main aim of this study is therefore to investigate if stratification in Vortsjärv has changed in response to the large-scale decline in surface wind speed or to some other factor, and if the magnitude of observed atmospheric stilling is sufficient to influence stratification dynamics. Due to the lack of available long-term depth-resolved temperature data for Võrtsjärv, we restore a multi- 
decadal stratification history of the lake with the use of a numerical model and evaluate, in terms of a sensitivity analysis, changes in stratification during the past $\sim 30$ years, in response to atmospheric stilling.

\section{Study site}

This study took place in a large and shallow lake, Võrstjärv, situated in Central Estonia (58.29 ${ }^{\circ} \mathrm{N}, 26.03{ }^{\circ} \mathrm{E}$; Fig. 1a). The lake is eutrophic, characterised by the following mean concentrations: total phosphorus (TP) $54 \mu \mathrm{g} \mathrm{l}^{-1}$, total nitrogen (TN) $1.6 \mathrm{mg} \mathrm{l}^{-1}$, chlorophyll-a $24 \mu \mathrm{g} \mathrm{l}^{-1}$ (Tuvikene et al. 2004; Nõges et al. 2007), and typically has a Secchi depth of less than $1 \mathrm{~m}$.

\section{Methods}

\subsection{Lake water temperature observations}

Lake water temperatures used in this investigation were as follows: (i) high-resolution lake surface $(0.5 \mathrm{~m}$ from surface) and bottom $(0.5 \mathrm{~m}$ above bed) temperatures recorded with a PME

a
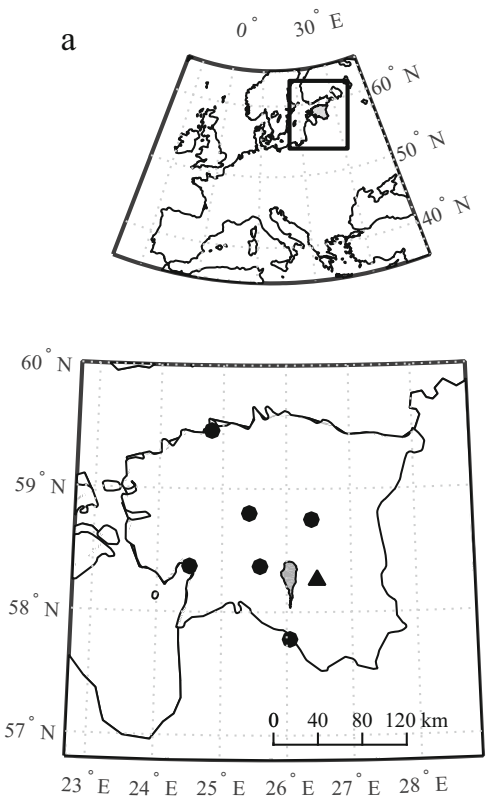
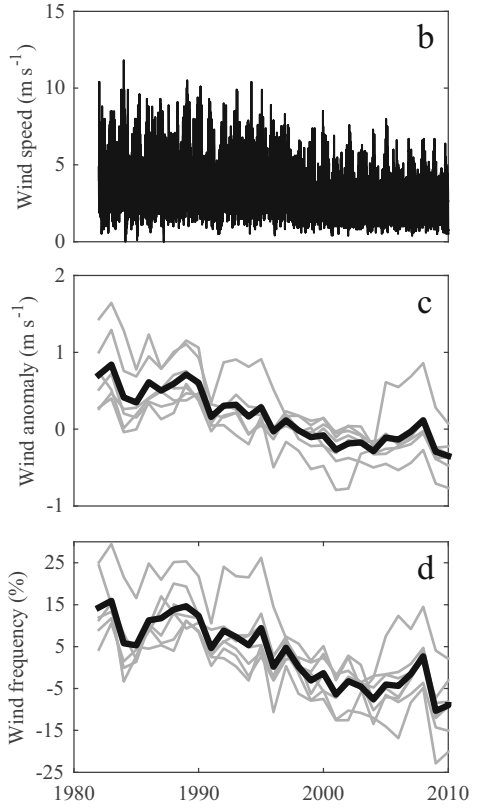

Fig. 1 a Map of study site. Shown is the location of Võrtsjärv (dark grey), the location of the meteorological station at Tõravere $\left(58.26^{\circ} \mathrm{N}, 26.47^{\circ} \mathrm{E}\right.$; triangle), and the stations in which wind speed measurements were available (circles): Pärnu-Sauga $\left(58.37^{\circ} \mathrm{N}, 24.50^{\circ} \mathrm{E}\right)$, Tallinn-Harku $\left(59.47^{\circ} \mathrm{N}, 24.82^{\circ} \mathrm{E}\right)$, Jõgeva $\left(58.75^{\circ} \mathrm{N}\right.$, $\left.26.39^{\circ} \mathrm{E}\right)$, Türi $\left(58.80^{\circ} \mathrm{N}, 25.42^{\circ} \mathrm{E}\right)$, Valga $\left(57.78^{\circ} \mathrm{N}, 26.05^{\circ} \mathrm{E}\right)$, and Viljandi $\left(58.37^{\circ} \mathrm{N}, 25.59^{\circ} \mathrm{E}\right)$. Also shown are observations of $\mathbf{b}$ daily-averaged wind speed measured at Tartu-Tõravere; $\mathbf{c}$ annually averaged wind speed anomaly (relative to 1990-2010 annual average $=3 \mathrm{~ms}^{-1}$ ); and $\mathbf{d}$ occurrence frequencies (in \%) for wind speeds $>3 \mathrm{~m} \mathrm{~s}^{-1}$. Grey lines illustrate the wind speeds for an individual meteorological station in Estonia, and the thick black line represents the regional average (computed as the arithmetic mean of all stations) 
MiniDOT logger at 10 min intervals from 2013 to 2015; and (ii) long-term observations of surface temperatures measured from 1982 to 2009 at approximately monthly intervals.

\subsection{Lake temperature model}

In this investigation, we use the one-dimensional process-based lake model, MyLake (v1.2; Saloranta and Andersen 2007). MyLake has been designed to simulate accurately the daily vertical profiles of lake water temperature and thus thermal and density stratification, and has been used successfully in numerous lakes from around the world (Dibike et al. 2012; Pätynen et al. 2014; Couture et al. 2015). The modelling principles of MyLake are similar to other onedimensional lake model codes, such as DYRESM-CAEDYM (Hamilton and Schladow 1997). The model code is written in MATLAB and has been designed to be computationally efficient and easily adaptable to different lakes. In addition to the model code, three different parameter and input data files are required to run MyLake. These include (i) time series of daily atmospheric data, (ii) lake morphometry and initial vertical water temperature profiles, and (iii) model parameter values. The model also requires information on water clarity, included in terms of the light attenuation coefficient $\left(K_{d}, \mathrm{~m}^{-1}\right)$. In this study, we followed the methods of Woolway et al. (2015b) and estimated $K_{d}$ as a function of secchi depth $\left(z_{\text {secchi }}\right)$ as: $K_{d}=1.75 /$ $z_{\text {secchi }}$. An average $z_{\text {secchi }}$ was estimated from monthly averaged observations from Võrtsjärv. Initial profiles of water temperature were set equivalent to the surface air temperature at the start of the investigation. Thus, the water column was assumed vertically mixed. Model parameters were kept similar to those suggested in the user manual. MyLake also contains five switches, which can be used to disable some particular model processes if desired. These include (i) snow compaction, (ii) river inflow, (iii) sediment heat flux, (iv) self-shading, and (v) tracer simulation. Each of these features was disabled in this investigation. Simulated temperatures were validated for a 3-year period using the high-resolution lake surface and bottom temperatures described above.

\subsection{Atmospheric forcing data}

MyLake requires time series of atmospheric forcing data. Specifically, data for air pressure at station level $(\mathrm{hPa})$, air temperature at $2 \mathrm{~m}\left({ }^{\circ} \mathrm{C}\right)$, relative humidity at $2 \mathrm{~m}(\%)$, precipitation

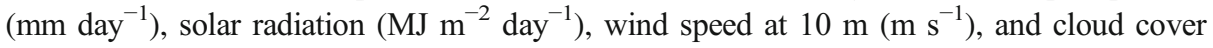
fraction (ccf, 0-1) are required. Atmospheric pressure, $p$, was assumed constant in this modelling study and was estimated based on the surface elevation of the lake. We calculated pressure as (Woolway et al. 2015c):

$$
p=\left[101325\left(1-\mathrm{h} \times 2.25577 \times 10^{-5}\right)^{5.25588}\right] / 100,
$$

where $h$ is altitude (m). Using this calculation, we used a constant value of $1009 \mathrm{hPa}$. The only atmospheric forcing parameter that was not measured in situ was ccf. Therefore, we estimated $\operatorname{ccf}$ as $\operatorname{ccf}=1-s$, where $s$ is the ratio of the measured solar radiation to the estimated clear-sky solar radiation at the lake surface, which was estimated following Woolway et al. (2015c). Specifically, the algorithm requires information on air temperature and relative humidity, and can be used to estimate clear-sky radiation at hourly resolution. Daily-averaged $c c f$ was then calculated and used as an input in MyLake. 
Atmospheric forcing data used in this investigation were available from two different sources: (i) a monitoring buoy situated on Võrtsjärv, equipped with a Vaisala multi-weather station (WXT520) and Li-Cor pyranometer at a height of $2 \mathrm{~m}$ above the lake surface; and (ii) a meteorological station situated in Tõravere $\left(58.26^{\circ} \mathrm{N}, 26.47^{\circ} \mathrm{E}\right), 30 \mathrm{~km}$ from the lake, data for which were provided by the Estonian Environmental Agency. These two datasets were used in the modelling study. In addition to the observations available from Tõravere, we also analysed wind speed observations from six other meteorological stations situated throughout Estonia. Wind speed measurements from Pärnu-Sauga $\left(58.37^{\circ} \mathrm{N}, 24.50{ }^{\circ} \mathrm{E}\right.$; 1973-2014) and TallinnHarku (59.47 $\left.{ }^{\circ} \mathrm{N}, 24.82^{\circ} \mathrm{E} ; 1973-2016\right)$ were available from HadISD (Dunn et al. 2012), which is a quality-controlled synoptic meteorological dataset used for climate applications at sub-daily resolution. Wind speed measurements from Jõgeva $\left(58.75^{\circ} \mathrm{N}, 26.39^{\circ} \mathrm{E}\right)$, Türi $(58.80$ $\left.{ }^{\circ} \mathrm{N}, 25.42^{\circ} \mathrm{E}\right)$, Valga $\left(57.78^{\circ} \mathrm{N}, 26.05^{\circ} \mathrm{E}\right)$, and Viljandi $\left(58.37^{\circ} \mathrm{N}, 25.59^{\circ} \mathrm{E}\right)$ meteorological stations were available from the Estonian Environmental Agency.

\subsubsection{Scaling of atmospheric data}

To scale the land-based measurements to be representative of over-lake conditions, we compared the recent (2013-2015) in situ observations with those measured at Tartu-Tõravere station. Observations of solar radiation, relative humidity, and air temperature were similar among the sites. Specifically, solar radiation had an $R^{2}$ of 0.96 and a root mean square error (RMSE) of $22 \mathrm{~W} \mathrm{~m}^{-2}$; air temperature had an $R^{2}$ of 0.98 and a RMSE of $0.88{ }^{\circ} \mathrm{C}$; and relative humidity had an $R^{2}$ of 0.86 and a RMSE of $1.65 \%$, all of which were statistically significant (two-tail $t$ test $p<0.001$ ). To compare wind speed measurements between land and lake, we first converted the over-lake measurements to a standard height of $10 \mathrm{~m}$, similar to that measured over land. Numerous methods have been proposed to convert wind speed, $u_{\mathrm{z}}$, at the measurement height, $z$, to wind speed at $10 \mathrm{~m}, u_{10}$ (e.g., Amorocho and DeVries 1980; Large and Pond 1981). Most of these methods, however, assume a neutral atmospheric boundary layer, which, in lakes, is not often true and can therefore bias $u_{10}$ estimates. In this study, we not only corrected for measurement height and wind speed but also corrected for atmospheric stability, using the algorithm developed by Zeng et al. (1998) and included in the Lake Heat Flux Analyzer program (http:/heatfluxanalyzer.gleon.org/; Woolway et al. 2015c). After converting $u_{\mathrm{z}}$ to $u_{10}$, we compared the lake and land-based wind measurements, $u_{\text {lake }}$ and $u_{\text {land }}\left(R^{2}=0.6\right.$, two-tail $t$ test $\left.p<0.001\right)$, and found a relationship of

$$
u_{\text {lake }}=2.17 \times u_{\text {land }},
$$

which was then used to scale the long-term wind measurements to be representative of overlake conditions.

\subsection{MyLake experiments}

To evaluate the relative contribution of changes in air temperature and changes in wind speed, the two variables that varied significantly in recent years (see Section 4), on stratification dynamics in Võrtsjärv, we performed a series of MyLake simulations. Firstly, lake temperatures were simulated using the observed atmospheric forcing data over the 28-year period. These simulations were then repeated, except using the wind speed observations for 1982, the first year of available meteorological data, for every year, thereby removing any effect of wind 
speed change from the results. A similar set of simulations were then performed but with the air temperatures, rather than the wind speeds, held at the 1982 levels in order to remove the impact of systematic changes in air temperature. The first year of observations (i.e., 1982) was chosen to represent conditions that have not varied since the start of the investigation, and thus to investigate how would stratification in the lake have evolved had air temperatures or wind speed not changed since 1982. To ensure that using the data from 1982 to determine a constant annual cycle in both wind speed and air temperature did not bias our modelling results, we repeated all simulations but replacing the 1982 constant annual cycle with the climatological average daily meteorological forcing for both these variables. This represents the mean atmospheric conditions for each day throughout the 28 years. These model results were then compared to those produced from the first sensitivity analysis (i.e., using the 1982 data as a constant annual cycle) for validation.

Though vertical temperature differences are often used to define stratification (Stefan et al. 1996; Woolway et al. 2014), stratification is the result of the associated density differences and these vary non-linearly with temperatures. Thus, at $5{ }^{\circ} \mathrm{C}$, a $1{ }^{\circ} \mathrm{C}$ temperature difference is equivalent to less than a $0.025 \mathrm{~kg} \mathrm{~m}^{-3}$ density difference, while at $19{ }^{\circ} \mathrm{C} \mathrm{a} 1{ }^{\circ} \mathrm{C}$ temperature difference represents more than a $0.2 \mathrm{~kg} \mathrm{~m}^{-3}$ density difference. To capture all stratification periods here, we therefore used a threshold of a $0.025 \mathrm{~kg} \mathrm{~m}^{-3}$ density difference between the top and the bottom of the lake to define stratification. For all model experiments, the effects of wind speed and air temperature on stratification were determined by firstly calculating the number of stratified days per year (May-August, see Section 4). A linear regression model was then used to evaluate the rate of change in the number of stratified days during the 28 -year period. To evaluate if the regression slopes were different among model runs, and thus determine if the influence of air temperature and/or wind speed on stratification were statistically distinguishable, we followed an analysis of covariance (ANCOVA) approach. Specifically, ANCOVA was used to compare the different regression slopes by testing the effect of a categorical factor (e.g., different model) on the dependent variable (e.g., the number of stratified days; y-variable) while controlling for the effect of the continuous co-variable (e.g., time; $\mathrm{x}$-variable). A statistically significant interaction between the categorical factors demonstrates that the regressions have statistically different slopes. In contrast, if the interaction is not statistically significant, the covariate has the same effect for all levels of the categorical factor, meaning that a single regression line can be used to represent the different relationships. All calculations in this study were performed in R (R Development Core Team 2014).

\section{Results}

\subsection{Long-term atmospheric forcing in Võrtsjärv}

Over the last 28 years, wind speed has been declining in all seven of the meteorological stations in Estonia (Fig. 1). This is seen in the raw daily data from Tartu-Tõravere (Fig. 1b) and in the annually averaged wind speeds from all seven meteorological stations situated throughout Estonia (Fig. 1c). The annually averaged wind speeds are shown in Fig. 1c as anomalies relative to the 1990-2010 average to account for the different magnitude of wind speeds observed throughout Estonia. The regional average change is $-0.29 \pm 0.03 \mathrm{~m} \mathrm{~s}^{-1}$ decade $^{-1}$, varying from $-0.11 \pm 0.05$ to $-0.68 \pm 0.05 \mathrm{~m} \mathrm{~s}^{-1}$ decade $^{-1}$ in Tartu-Tõravere and Valga, respectively (Fig. 1c), with declines in all stations being statistically significant (two-tail $t$ test 
$p<0.05)$. In addition, the observational data suggests a decrease in the frequency of wind speeds $>3 \mathrm{~m} \mathrm{~s}^{-1}$ (calculated as the $\%$ of time in which wind speeds exceeded $3 \mathrm{~m} \mathrm{~s}^{-1}$ during a given year. This threshold was chosen based on the mean wind speed calculated in TartuTõravere throughout the study period $=3 \mathrm{~m} \mathrm{~s}^{-1}$ ), demonstrating an increase in the frequency of calm days (shown as negative values in Fig. 1d) leading to a regionally averaged change of $-6.25 \pm 0.77 \%$ decade $^{-1}$ (Fig. 1d). Among the other meteorological data measured in situ, only air temperature experienced a statistically significant $(p<0.05)$ change since 1982 , where the annually averaged air temperature increased at a rate of $0.52 \pm 0.21^{\circ} \mathrm{C} \operatorname{decade}^{-1}(p=0.0185)$. None of the other atmospheric forcing data experienced a significant change in their annual averages during the study period, nor did the lake water level (Fig. 2).

\subsection{Lake temperature modelling}

The simulations of temperature in both surface and bottom waters of Võrtsjärv showed very good agreement with observed data during the 3-year validation study (Fig. 3a, b). In general,

Fig. 2 Observations of annually averaged a surface air temperature; b relative humidity; c global solar radiation; $\mathbf{d}$ precipitation; and $\mathbf{e}$ mean depth, in Võrtsjärv. Meteorological data were measured $30 \mathrm{~km}$ from the lake at Tartu-Tõravere meteorological station. Linear regressions of the statistically significant $(p<0.05)$ relationships are shown
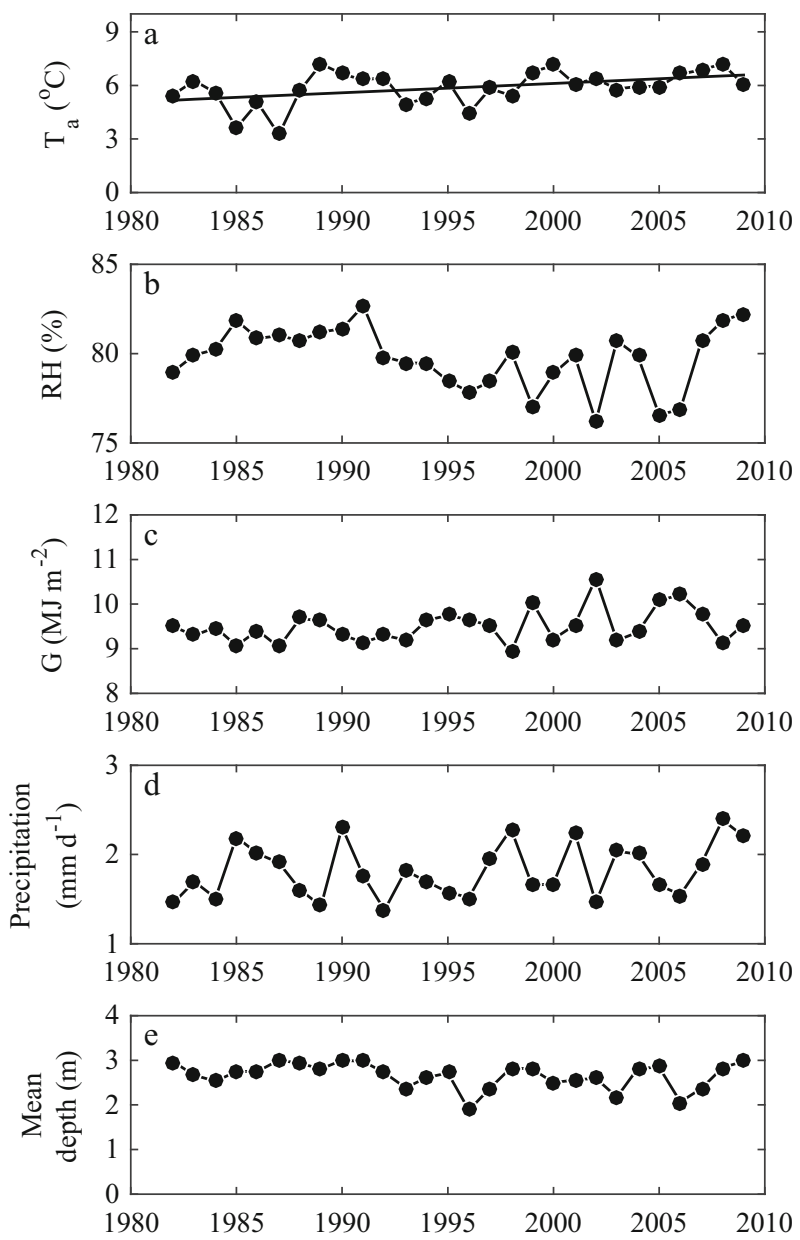

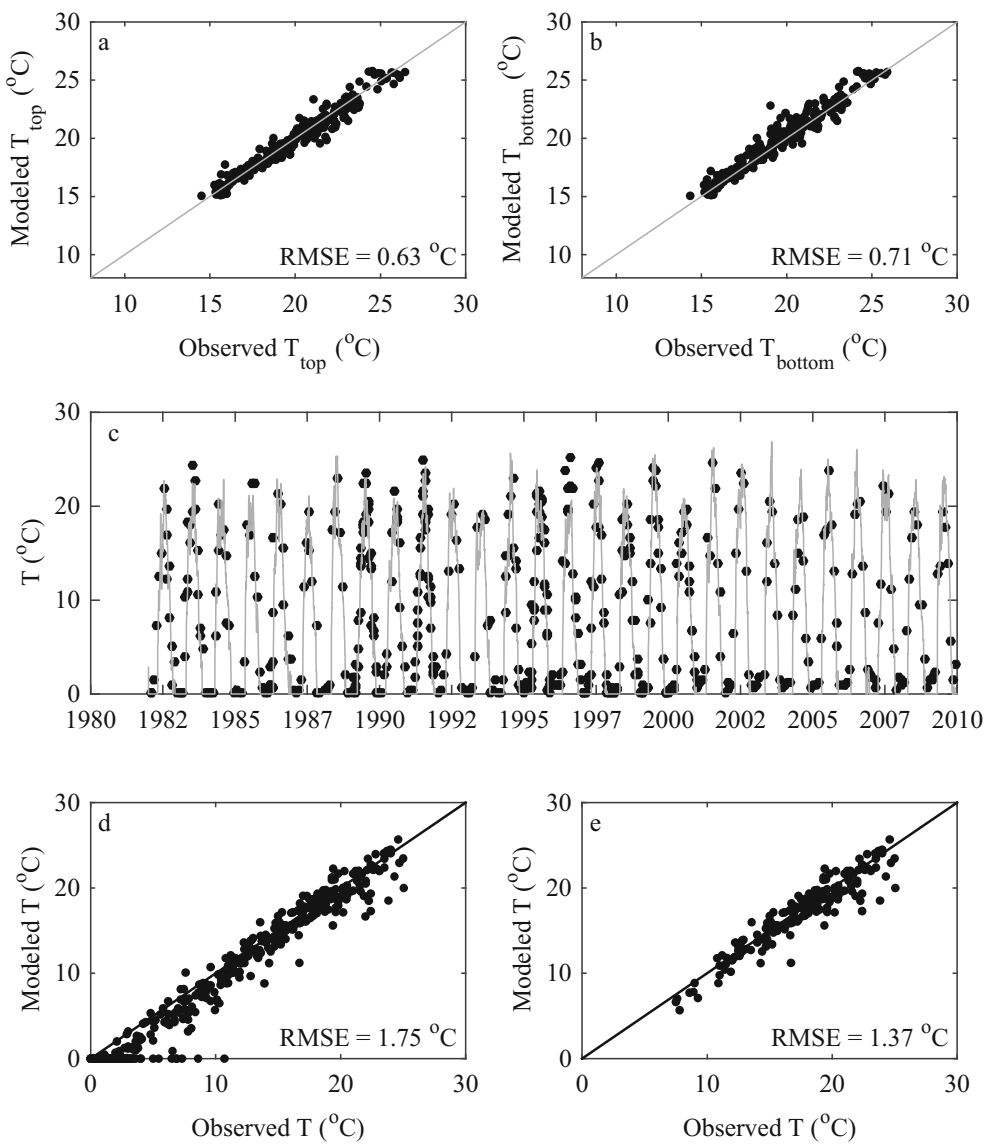

Fig. 3 Comparison of modelled and observed a surface and b bottom water temperatures for 2013-2015. c Comparison of long-term modelled (grey line) and observed (black dots) lake surface water temperature, showing a comparison $\mathbf{d}$ throughout the year and e during spring/summer (MJA)

lake surface water temperatures were simulated with the higher accuracy, although the mean absolute difference (MAD) and RMSE of bottom water temperature simulations were under $1{ }^{\circ} \mathrm{C}$. The mean MAD among the 3 years were $0.48{ }^{\circ} \mathrm{C}$ (surface) and $0.53{ }^{\circ} \mathrm{C}$ (bottom), and the mean RMSE among the 3 years were $0.63{ }^{\circ} \mathrm{C}$ and $0.71{ }^{\circ} \mathrm{C}$ for surface and bottom waters, respectively. The maximum difference between observed and simulated surface water temperatures was $1.75^{\circ} \mathrm{C}$. Bottom water temperature simulations were marginally better in terms of maximum difference, which was calculated as $1.29{ }^{\circ} \mathrm{C}$.

Using 28 years of atmospheric forcing data from Tartu-Tõravere, MyLake generally captured the temporal dynamics of lake surface temperatures with great success (Fig. 3c). The model performed less well in winter, occasionally resulting in large temperature differences between observed and modelled values (Fig. 3d), in particular during periods of ice cover, which is an important factor for lakes in the northern hemisphere, having decreased in recent decades (Magnuson et al. 2000; Kheyrollah Pour et al. 2012; Duguay et al. 2013). During the May-August (MJJA) months, modelled temperatures closely matched those observed $\left(\mathrm{MAD}=0.97{ }^{\circ} \mathrm{C}\right.$; $\mathrm{RMSE}=1.37^{\circ} \mathrm{C} ; R^{2}=0.88$; Fig. 3e). These months were used to assess changes in stratification from the model. 


\subsubsection{Modelled changes in thermal stratification}

Simulated water density profiles for the 28-year period reveal a noticeable change in recent years with a substantial increase in the average top-bottom density difference (Fig. 4a). During the start of the investigation, the density difference between top and bottom waters was minimal, with bottom waters only marginally exceeding those at the surface. However, in recent years, the density difference increased noticeably. The model results demonstrate a significant relationship between wind speed and the number of stratified days in MJJA over the 28 years (Fig. 4b). Specifically, we find that the number of stratified days per year in Võrtsjärv increased at a rate of 3.16 $\pm 0.86(p=0.001)$ days with a $1 \mathrm{~m} \mathrm{~s}^{-1}$ decrease in annually averaged wind speed. Analysis of the model results for the past 28 years demonstrated an increase of over $80 \%$ in the number of stratified days in the second half of the study period (19952009) compared to the first half (1982-1995) (Fig. 4c) and that the overall number of stratified days increased at a rate of $2.1 \pm 0.6$ days per decade (two-tail $t$ test $p<0.001)$.
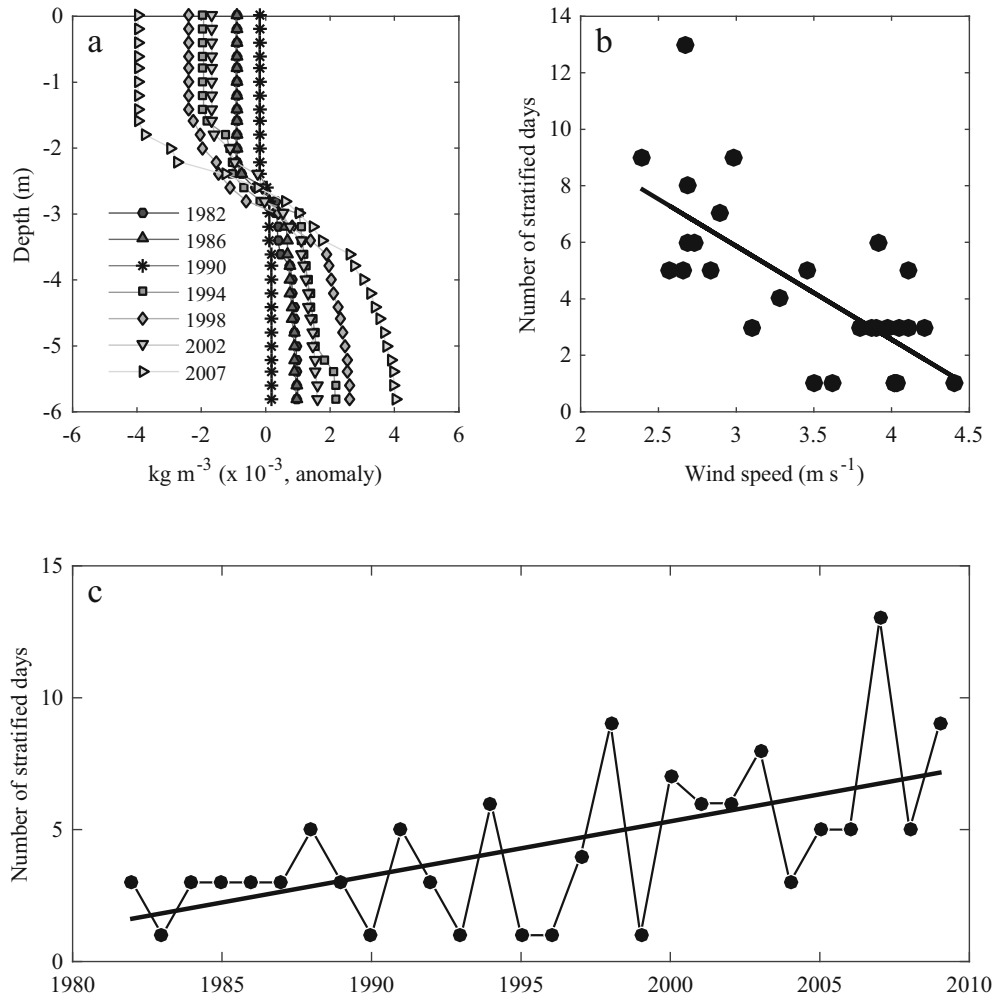

Fig. 4 a Simulated water column density profiles averaged for 4 months during spring/summer (MJJA) for selected example years. Shown are the density profile anomalies relative to the 1982 to 2010 average density profile. b Relationship between the average wind speeds measured at Tartu-Toravere meteorological station and the simulated number of stratified days from model runs with observed meteorological data. $\mathbf{c}$ Time series of the simulated number of stratified days from model runs with observed meteorological data 


\subsubsection{Impacts of wind change versus air temperature change}

Our model sensitivity analysis illustrates that the decrease in wind speed is the key influence on the number of stratified days and that the influence of increasing air temperature was minimal. Running MyLake with a constant annual air temperature cycle demonstrates that the number of stratified days still increased markedly in recent years (Fig. 5a), at a rate of 1.7 \pm 0.6 days per decade (two-tail $t$ test $p<0.001$ ). This calculated rate of change in the number of stratified days is statistically indistinguishable compared to the model run using the full observational data, as evaluated via ANCOVA between regression slopes. In contrast, when the annual cycle in surface wind speed was kept constant, but air temperature allowed to vary, the model results show no statistically significant increase $(p>0.05)$ in the number of stratified days during the past 28 years (Fig. 5b). We evaluated further the impact of changing air temperature on the number of stratified days by running the model with air temperatures from 1987 (Fig. 5c) and 2009 (Fig. 5d), the coolest and warmest years, respectively, held constant. The calculated number of stratified days showed a statistically significant increase in both

Fig. 5 Comparisons of the number of stratified days from model runs with a constant 1982 air temperature annual cycle; $\mathbf{b}$ constant 1982 wind speed annual cycle; c constant 1987 air temperature annual cycle; and $\mathbf{d}$ constant 2009 air temperature annual cycle. Linear regressions of the statistically significant $(p<0.05)$ relationships are shown
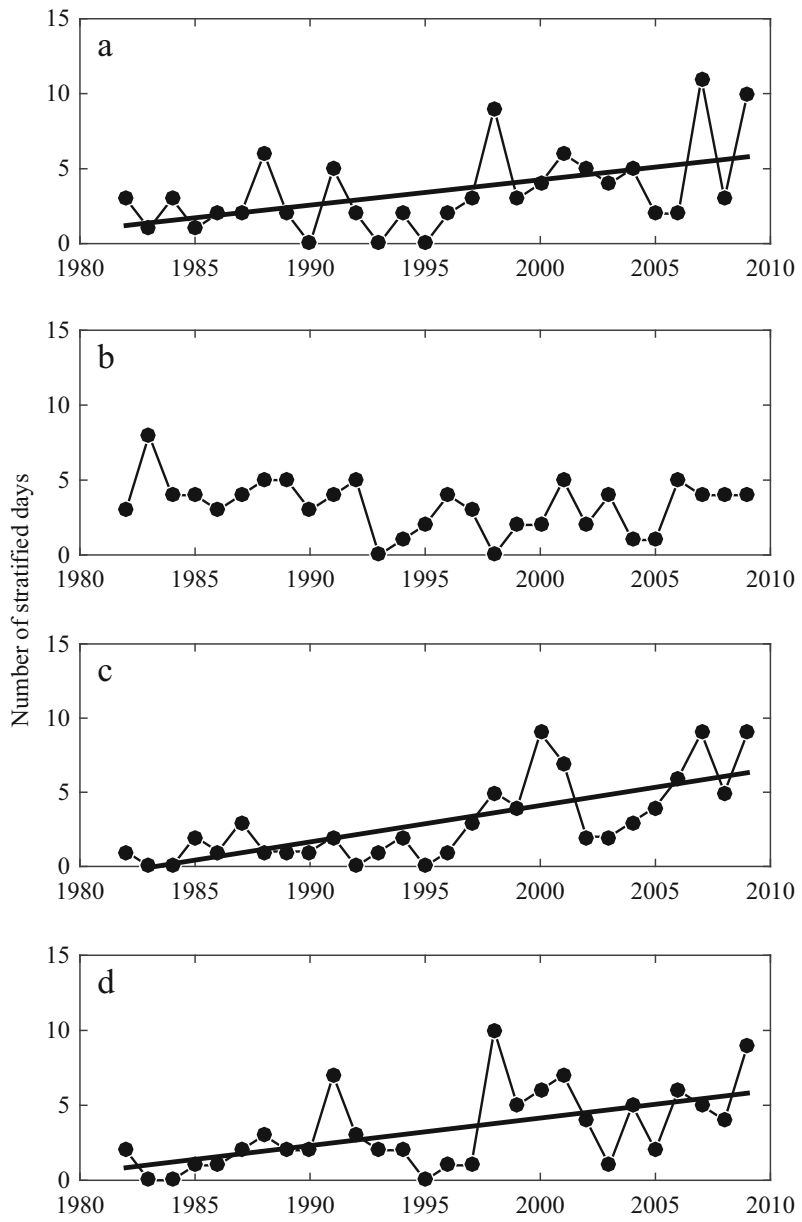
model runs, with neither of these simulations being statistically different from the model using observed meteorological forcing data. In particular, the interaction term in the ANCOVA model demonstrated that they were not significant $(p>0.1)$, meaning that the regression slopes were statistically indistinguishable. We repeated all MyLake simulations using the daily climatological annual cycle in both wind speed and air temperature instead of using the 1982 values held constant. Similar to the other model runs, the regression slopes were not statistically different and wind speed was again found to be the dominant driver for the increased number of stratified days in recent years.

\section{Discussion}

Based on long-term meteorological data available from in situ meteorological stations in Estonia, we found a large-scale decrease in surface wind speeds during the past 230 years, consistent with other locations globally (Vautard et al. 2010). Previous investigations attribute this regional (i.e., in Estonia) decrease to changes in atmospheric circulation (Jaagus and Kull 2011) with others suggesting that changes in surface roughness surrounding the meteorological stations (Suursaar and Kullas 2006), and inconsistencies introduced by instrumental change (Jaagus and Kull 2011), may bias the observed trends. Analysis of wind speed data from seven meteorological stations, some of which were separated by up to $200 \mathrm{~km}$, provide evidence against the latter and suggest that the observed decrease in surface wind speed is not confined to a particular location or meteorological station in Estonia. In this investigation, we examined the influence of this large-scale decrease in surface wind speed on thermal stratification in Võrtsjärv, a large and shallow lake situated in Central Estonia.

High-resolution in situ temperature measurements from Võrtsjärv illustrate that, in recent years, the lake stratifies for several days during spring/summer. This is unexpected, as previous investigations have described Võrtsjärv as traditionally having no thermal stratification (Frisk et al. 1999). In this study, we found a strong influence of atmospheric stilling on stratification dynamics and suggest that a decrease in surface wind speed has resulted in an increase in the number of stratified days in recent years. In particular, our model results illustrate that the number of stratified days in Võrtsjärv has increased at a rate of 2 days per decade. Few studies have examined impacts of systematic wind speed changes on lake stratification, but those that do have tended to focus on the influence of local changes such as deforestation and forest regrowth (France 1997; Tanentzap et al. 2007). To our knowledge, this is the first study to relate regional atmospheric stilling to changes in lake stratification.

In contrast, many studies have discussed the likely effects of rising air temperatures on lake stratification and the focus on this one parameter has drawn attention away from the possible influences of other aspects of directional climate changes, with only a very few studies having investigated the response of lake thermal dynamics to changing surface wind speeds (Tanentzap et al. 2008; Desai et al. 2009; Kerimoglu and Rinke 2013). Despite air temperatures increasing in Estonia $\left(0.52{ }^{\circ} \mathrm{C}\right.$ decade $\left.^{-1}\right)$, at a rate twice that of the global average $\left(0.25{ }^{\circ} \mathrm{C}\right.$ decade $\left.^{-1}\right)$ (Hartmann et al. 2013) over a similar time period (1979-2012), our modelling suggests this increase has not been sufficient to nudge the large, shallow, typically mixed, Võrtsjärv to a different mixing regime. The contemporaneous changes in wind speed, though, have been sufficient to do this. This suggests that ongoing changes in wind speed resulting from atmospheric stilling may be a more potent driver of stratification change in 
some lakes than the changes in air temperature, despite the overwhelming preference for studying the latter. Other factors are also known to influence stratification in some lakes. For example, water level has previously been shown to be an important factor influencing thermal stratification in Lake Kinneret, Israel (Rimmer et al. 2011). Moreover, lake water level has been described as one of the most influential factors affecting the physics (Nõges \& Järvet 1995), chemistry (Nõges \& Nõges 1999), and biology (Nõges et al. 2003; Järvalt et al. 2005) of Võrtsjärv. However, in this study we found no systematic change in water level during the past 28 years (e.g., Fig. 2e).

Our study highlights the importance of taking high frequency measurements in mixed and polymictic systems, without which transient periods of stratification and long-term changes to stratification may be missed. Such measurements are proliferating globally (e.g., Woolway et al. 2016) enabling more detailed studies of stratification to now take place than would have been possible just a decade ago. High frequency, in situ measurements are being further complemented by advancements in Earth Observation.

Projected changes in lake stratification under future climate are likely to induce a variety of impacts on the ecology and chemistry of lakes, which in turn will have implications for water quality and for adaptation strategies and management of lakes. For example, thermal stratification has been shown to restrict the supply of oxygen to deep waters (Foley et al. 2012; North et al. 2014), leading to deoxygenation in productive lakes and potential increases in the rate of recycling of phosphorus from the sediment to the water column (Søndergaard et al. 2003), with consequences for lake productivity (O’Reilly et al. 2003; Verburg et al. 2003). Also, ecosystem properties such as metabolism (Staehr et al. 2010) and gas flux at the air-water interface (Coloso et al. 2011) are highly influenced by lake thermal dynamics, thus being important for the global carbon cycle. Changing stratification can affect the likelihood of cyanobacterial bloom formation (Paerl and Huisman 2008; Jöhnk et al. 2008) and, through the impact on both temperature and oxygen, can impact the available habitat for fish species (Jones et al. 2008; Kangur et al. 2016). Our results illustrate that if wind speeds continue to decrease, Võrtsjärv may stratify for longer, having large consequences for the ecosystem. With lakes worldwide being subjected to increased air temperature against the potential backdrop of decreasing wind speed, future investigations should aim to understand the relative importance of these factors and how they interact to influence thermal stratification and potentially impair water quality.

Acknowledgements RIW was funded by EUSTACE (EU Surface Temperature for All Corners of Earth) which received funding from the European Union's Horizon 2020 Programme for Research and Innovation, under Grant Agreement no 640171. Data collection in this manuscript was collected under the Estonian Ministry of Education and Research grants (IUT 21-02 and PUT 777). Initial discussions for this work took place at a NETLAKE (Networking Lake Observatories in Europe) working group meeting in Riga, Latvia. The authors are grateful for the support of NETLAKE and its chair, Eleanor Jennings. We thank three anonymous reviewers for suggestions that improved an earlier version of this manuscript.

Authorship statement PN, AL, and PM developed the concept of the study; RIW, IDJ, and AL designed the model experiments; RIW and IDJ analysed the results; RIW and PM led the paper writing; all authors contributed to discussions, revisions and the production of the final manuscript.

Open Access This article is distributed under the terms of the Creative Commons Attribution 4.0 International License (http://creativecommons.org/licenses/by/4.0/), which permits unrestricted use, distribution, and reproduction in any medium, provided you give appropriate credit to the original author(s) and the source, provide a link to the Creative Commons license, and indicate if changes were made. 


\section{References}

Amorocho J, DeVries JJ (1980) A new evaluation of the wind stress coefficient over water surfaces. J Geophys Res 85:433-442

Bichet A, Wild M, Folini S, Schär C (2012) Causes for decadal variations of wind speed over land: sensitivity studies with a global climate model. Geophys Res Lett 39(11). doi:10.1029/2012GL051685

Boehrer B, Schultze M (2008) Stratification of lakes. Rev Geophys 46(2). doi:10.1029/2006RG000210

Churchill JH, Kerfoot WC (2007) The impact of surface heat flux and wind on thermal stratification in Portage Lake, Michigan. J Great Lakes Res 33:143-155

Coloso JJ, Cole JJ, Pace ML (2011) Short-term variation in thermal stratification complicates estimation of lake metabolism. Aquat Sci 73:305-315

Couture R-M, de Wit HA, Tominaga K, Kiuru P, Markelov I (2015) Oxygen dynamics in a boreal lake responds to long-term changes in climate, ice phenology, and DOC inputs. J Geophys Res Biogeosci 120:2441-2456

Desai A et al (2009) Stronger winds over a large lake in response to weakening air-to-lake temperature gradient. Nat Geosci 2:855-858

Dibike Y, Prowse T, Bonsal B, Rham LD, Saloranta T (2012) Simulation of North American lake-ice cover characteristics under contemporary and future climate conditions. Int J Climatol 32:695-709

Dunn RJH, Willett KM, Thorne PW et al (2012) HadISD: a quality-controlled global synoptic report database for selected variables at long-term stations from 1973-2011. Clim Past 8:1649-1679. doi:10.5194/cp-8-16492012

Duguay C, Brown L, Kang K-K, Kheyrollah Pour H (2013) Arctic-lake ice, in "State of the Climate in 2012". Bull Am Meteorol Soc 94:S124-S126

Eastman R, Warren SG (2013) A 39-yr survey of cloud changes from land stations worldwide 1971-2009: longterm trends, relation to aerosols, and expansion of the tropical belt. J Clim 26:1286-1303

Elo A-R, Huttula T, Peltonen A, Virta J (1998) The effects of climate change on the temperature conditions of lakes. Boreal Environ Res 3:137-150

Foley B, Jones ID, Maberly SC, Rippey B (2012) Long-term changes in oxygen depletion in a small temperate lake: effects of climate change and eutrophication. Freshw Biol 57:278-289

France R (1997) Land-water linkages: influences of riparian deforestation on lake thermocline depth and possible consequences for cold stenotherms. Can J Fish Aquat Sci 54:1299-1305

Frisk T, Bilaletdin Ä, Kaipainen H, Malve O, Möls M (1999) Modelling phytoplankton dynamics of the eutrophic Lake Võrtsjärv, Estonia. Hydrobiologia 414:59-69

Hamilton DP, Schladow SG (1997) Prediction of water quality in lakes and reservoirs. Part 1-model description. Ecol Model 96:91-110

Hartmann DL (2013) IPCC fifth assessment report, climate change 2013. In: Stocker TF (ed) The physical science basis. Cambridge Univ. Press, Cambridge

Heiskanen J, Mammarella I, Ojala A, Nordbo A (2015) Effects of water clarity on lake stratification and lakeatmosphere heat exchange. J Geophys Res - Atmos 120:7412-7428

Hutchinson E (1957) A treatise on limnology vol 1. Wiley, New York, 1015p

Jaagus J, Kull A (2011) Changes in surface wind directions in Estonia during 1966-2008 and their relationship with large-scale atmospheric circulation. Estonian J Earth Sci 60:220-231

Jaani A (1973) Hydrobiology. In: Timm, T. (Ed.), L. Võrtsjärv (in Estonian) Valgus, Tallinn, pp. 37-60

Järvalt A, Laas A, Nõges P, Pihu E (2005) The influence of water level fluctuations and associated hypoxia on the fishery of Lake Vortsjarv, Estonia. Ecohydrol Hydrobiol 4:487-497

Jöhnk KD, Huisman J, Sharples J, Sommeijer B, Visser PM, Stroom JM (2008) Summer heatwaves promote blooms of harmful cyanobacteria. Glob Change Biol 14:495-512

Jones ID, Winfield IJ, Carse F (2008) Assessment of long-term changes in habitat availability for Arctic charr (Salvelinus alpinus) in a temperate lake using oxygen profiles and hydroacoustic surveys. Freshwater Biol 53:393-402

Kangur K, Ginter K, Kangur P, Kangur A, Nõges P, Laas A (2016) Changes in water temperature and chemistry preceding a massive kill of bottom-dwelling fish: an analysis of high-frequency buoy data of shallow Lake Võrtsjärv (Estonia). Inland Waters 6:535-542. doi:10.5268/IW-6.4.869

Kerimoglu O, Rinke K (2013) Stratification dynamics in a shallow reservoir under different hydrometeorological scenarios and operational strategies. Wat Resour Res 49:7518-7527

Kirillin G (2010) Modeling the impact of global warming on water temperature and seasonal mixing regimes in small temperate lakes. Boreal Environ Res 15:279-293

Kheyrollah Pour H, Duguay C, Martynov A, Brown LC (2012) Simulation of surface temperature and ice cover of large northern lakes with 1-D models: a comparison with MODIS satellite data and in situ measurements. Tellus A 64:17614. doi:10.3402/tellusa.v64i0.17614 
Laas A, Nõges P, Kõiv T, Nõges T (2012) High frequency metabolism study in a large and shallow temperate lake revealed seasonal switching between net autotrophy and net heterotrophy. Hydrobiologia 694:57-74

Large WG, Pond S (1981) Open ocean momentum flux measurements in moderate to strong winds. J Phys Oceanogr 11:324-336

Lewis WMJR (1983) A revised classification of lakes based on mixing. Can J Fish Aquat Sci 40:1779-1787

Livingstone DM (2003) Impact of secular climate change on the thermal structure of a large temperate central European lake. Clim Chang 57:205-225

Magnuson JJ et al (2000) Historical trends in lake and river ice cover in the Northern Hemisphere. Science 289: 1743-1746

Nõges P, Järvet A (1995) Water level control over light conditions in shallow lakes. Report Series in Geophysics. University of Helsinki 32:81-92

Nõges P, Nõges T (2012) Lake Võrtsjärv. In: Bengtsson L, Herschy R, Fairbridge R (eds) Encyclopedia of lakes and reservoirs. Springer, Dordrecht, pp 850-863

Nõges T, Järvet A, Kisand A, Laugaste R, Loigu E, Skakalski B, Nõges P (2007) Reaction of large and shallow lakes Peipsi and Võrtsjärv to the changes of nutrient loading. Hydrobiologia 584:253-264

Nõges T, Nõges P (1999) The effect of extreme water level decrease on hydrochemistry and phytoplankton in a shallow eutrophic lake. Hydrobiologia 408:277-283

Nõges T, Nõges P, Laugaste R (2003) Water level as the mediator between climate change and phytoplankton composition in a large shallow temperate lake. Hydrobiologia 506:257-263

North RP, North RL, Livingstone DM, Köster O, Kipfer R (2014) Long-term changes in hypoxia and soluble reactive phosphorus in the hypolimnion of a large temperate lake: consequences of a climate regime shift. Glob Change Biol 20:811-823

O’Reilly CM, Alin SR, Plisner P, Cohen AS, McKee BA (2003) Climate change decreases aquatic ecosystem productivity of Lake Tanganyika. Nature 424:766-768

Paerl HW, Huisman J (2008) Blooms like it hot. Science 320:57-58

Pätynen A, Elliott JA, Kiuru P, Sarvala J, Ventelä A-M, Jones RI (2014) Modelling the impact of higher temperature on the phytoplankton of a boreal lake. Boreal Environ Res 19(1):66-78

R Development Core Team (2014) R: a language and environment for statistical computing. R Foundation for Statistical Computing, Vienna [Available at http://www.R-project.org/.]

Rimmer A, Gal G, Opher T, Lechinsky Y, Yacobi YZ (2011) Mechanisms of long-term variations in the thermal structure of a warm lake. Limnol Oceanogr 56:974-988

Saloranta TM, Andersen T (2007) MyLake - a multi-year lake simulation model code suitable for uncertainty and sensitivity analysis simulations. Ecol Model 207:45-60

Shatwell T, Adrian R, Kirillin G (2016) Plantonik events may cause polymictic-dimictic regime shifts in temperate lakes. Sci Reports 6(24361). doi:10.1038/srep24361

Søndergaard M, Jensen JP, Jeppesen E (2003) Role of sediment and internal loading of phosphorus in shallow lakes. Hydrobiologia 506:135-145

Staehr PA et al (2010) Lake metabolism and the diel oxygen technique: state of the science. Limnol Oceanogr Methods 8:628-644

Stefan HG, Hondzo M, Fang X, Eaton JG, McCormick JH (1996) Simulated long-term temperature and dissolved oxygen characteristics of lakes in the north-central United States and associated fish habitat limits. Limnol Oceanogr 41:1124-1135

Suursaar U, Kullas T (2006) Influence of wind climate on the mean sea level and current regime in the coastal waters of west Estonia, Baltic Sea. Oceanologia 48:361-383

Tanentzap AJ et al (2007) Cooling lakes while the world warms: effects of forest regrowth and increased dissolved organic matter on the thermal regime of a temperate, urban lake. Limnol Oceanogr 53:404-410

Tuvikene L, Kisand A, Tõnno I, Nõges P (2004) In: Pihu E, Raukas A, Haberman J (eds) Chemistry of lake water and bottom sediments. Estonian Encyclopaedia Publishers, Tallinn, pp 89-101

Vautard R, Cattiaux J, Yiou P, Thepaut J, Ciais P (2010) Northern Hemisphere atmospheric stilling partly attributed to an increase in surface roughness. Nat Geo Sci 3:756-761

Verburg P, Hecky RE (2009) The physics of the warming of Lake Tanganyika by climate change. Limnol Oceanogr 54:2418-2430

Verburg P, Hecky RE, Kling H (2003) Ecological consequences of a century of warming in Lake Tanganyika. Science 301:505-507

Wild M (2012) Enlightening global dimming and brightening. Bull Am Meteorol Soc 93(1):27-37

Woolway RI, Livingstone DM, Kernan M (2015a) Altitudinal dependence of a statistically significant diel temperature cycle in Scottish lochs. Inland Waters 5:311-316. doi:10.5268/IW-5.4.854

Woolway RI, Jones ID, Hamilton DP, Maberly SC, Muraoka K, Read JS, Smyth RL, Winslow LA (2015b) Automated calculation of surface energy fluxes with high-frequency lake buoy data. Environ Model Softw 70:191-198. doi:10.1016/j.envsoft.2015.04.013 
Woolway RI, Maberly SC, Jones ID, Feuchtmayr H (2014) A novel method for estimating the onset of thermal stratification in lakes from surface water measurements. Wat Resour Res 50. doi:10.1002/2013WR014975

Woolway RI, Jones ID, Feuchtmayr H, Maberly SC (2015c) A comparison of the diel variability in epilimnetic temperature for five lakes in the English Lake District. Inland Waters 5:139-154. doi:10.5268/IW-5.2.748

Woolway RI et al (2016) Diel surface temperature range scales with lake size. PLoS ONE 11(3):e0152466. doi:10.1371/journal.pone.0152466

Xu M, Chang CP, Fu C, Qi Y, Robock A, Robinson D, Zhang HM (2006) Steady decline of east Asian monsoon winds, 1969-2000: evidence from direct ground measurements of wind speed. J Geophys Res 111:D24111. doi:10.1029/2006JD007337

Zeng X, Zhao M, Dickinson RE (1998) Intercomparison of bulk aerodynamic algorithms for the computation of sea surface fluxes using TOGA COARE and TAO data. J Clim 11:2628e2644 